\title{
SMART TOURISM DESTINATION
}

\section{Monica FAUR ${ }^{1}$, Olimpia BAN ${ }^{2}$}

'Doctoral School of Economic Sciences, Faculty of Economic Sciences, University of Oradea, Oradea, Romania

${ }^{2}$ Department of Economics and Business, Faculty of Economic Sciences,

University of Oradea, Oradea, Romania

faurmonica1984@gmail.com

olimpiaban2008@gmail.com

\begin{abstract}
The dynamic of the contemporary society has determined the implementation of the technology in all areas of activity. The tourism sector has answered the new challenges by offering some alternatives aimed at ensuring the increase of the tourism destinations competitiveness: using ICT to collect data, information about tourists, using new technologies in order to increase tourists' satisfaction and locals' welfare; the interconnectivity of the interested parties (authorities, tourism service providers, tourists, locals) through digital platforms; offering a unique experience, customized services to tourists using ICT, increasing the degree of competitiveness of the tourism destinations and their sustainable development with the help of new technologies; the innovation offered by ICT as differentiation element of the tourism offers of a destination. Thus, the smart tourism destination represents an approach centred on capitalizing the advantages offered by ICT contributing to the increase of competitiveness and sustainability of tourism destinations. The purpose of this paper is to present different approaches of the smart tourism destination.
\end{abstract}

Keywords: tourism destination; smart tourism destination; ICT.

JEL Classification: A1; M1; Z3; Z31; Z32; Z33.

\section{Introduction}

According to the World Tourism Organization (2019) smart tourism is a step forward in respect to the destination management and it involves: management, innovation, technology, accessibility and sustainability (World Tourism Organization, Digital Transformation, 2019).

As far as the European Commission's approach is concerned, smart tourism is a type of tourism that answers the new challenges and demands of this sector, which undergoes continuous changes, including the evolution of the digital tools, products and services, equal opportunities of access to all tourists, sustainable development of the areas, support for creative industries and local heritage (European Commission, Tourism, 2020).

In 2018, the European Commission started for the first time a competition in order to designate the "European Capital of Smart Tourism". 38 cities and 19 Member States of the European Union applied for the title of European Capital of Smart Tourism in 2019. In 2019, the winners were: Helsinki and Lyon. In 2019, the competition for the European Capital of Smart Tourism was organized in 35 cities 
from 17 Member States of the European Union. Gothenburg and Málaga were declared winners of the title of European Capital of Smart Tourism for 2020.

The cities participating in the competition were invited to present and share their innovative projects, ideas and initiatives implemented in each of the four sections of the competition: accessibility (opportunity to travel for all tourists even for those with disabilities, means of transport, which ensures easy access to all categories of tourists), digitalization (offering products and services using ICT), sustainability (protection of natural and human resources in balance with the economic development), cultural heritage and creativity (efficient exploitation of the cultural heritage and creative industries so as to offer unique experiences to tourists) (European Commission, European Capital of Smart Tourism, 2020).

\section{Methodology of the research}

This paper seeks to highlight different approaches regarding smart tourism destination. The steps performed in carrying out this research were the following: studying the literature, selecting the papers according to the number of citations using the Google Scholar database, qualitative analysis of the selected papers and issuing some conclusions.

\subsection{Smart tourism destination}

Lamfus and Alzua-Sorzabal (2013) define the smart tourism destination by taking into account the manner in which technology can help the destination become a more suitable place to meet the needs of locals and tourists. As far as the "smart city" notion is concerned, Lamfus and Alzua-Sorzabal (2003) consider that the entire concept and its development is based on the development and implementation of the Information and communications technology (ICT) and on the involvement of the city's citizens.

The authors approach the concept through the implementation of new technologies in the performance of tourism activities, in order for these to contribute to the increase of tourists' satisfaction and the locals' welfare.

Buhalis and Amaranggana (2013) consider that the implementation of technology in tourism destinations requires interconnecting the interested parties by means of platforms, with the help of which information on tourism activities can be immediately accessed.

Buhalis and Amaranggana (2013) believe that the purpose of using ICT in tourism activities is to enhance the tourism experience, to improve the efficiency of resource management in order to maximize both the competitiveness of the destination and consumer satisfaction, while demonstrating long-term sustainability.

Buhalis and Amaranggana (2014) state that smart tourism destinations are essential for providing personalized services to tourists, taking into account several aspects including: real-time access to information in order to collect data regarding the users, giving feedback on the provided services as well as a dynamic platform, which would allow the exchange of information between the interested parties so as to promote integrated services.

The approach formulated by Buhalis and Amaranggana points out to the entire complexity of the concept in terms of the interested parties and of the advantages arising from the implementation of ICT in tourism destinations. 
Gretzel et al (2015) define smart tourism as the one supported by integrated efforts within a destination in order to find innovative ways to collect and capitalize the data derived from the exploitation of the infrastructure, social connections, government sources and people, together with the use of advanced technologies in order to transform them into experiences, valuable business proposals with a clear emphasis on efficiency, sustainability and new experiences during the trip.

The authors interpret the smart tourism destination as a useful tool for obtaining valuable information from all interested parties.

Lamfus et al (2014) consider that a tourism destination is smart when it intensively uses the technological infrastructure provided by a smart city to: improve the tourism experience and empower destination management organizations, local institutions and tourism companies in order to take decisions and act on the information collected, managed and processed through the technological infrastructure. In the authors' view, the use of ICT for obtaining valuable information represents the main advantage for the interested parties. Information that helps to establish decisions on the design of new tourism products and their marketing in the most advantageous conditions.

Lopez de Avila (2015) defines the smart tourism destination as being based on a state-of-the-art infrastructure, guaranteeing the sustainable development of tourism areas and facilitating the interaction and integration of tourists, improving the locals' quality of life. This definition is of topicality and it highlights the need to redirect the management policies of the tourism destination for the medium/long term performance of sustainable tourism activities in order to ensure the integration and interaction of tourists and the increase of locals' quality of life.

Xiang et al (2015) consider that the smart tourism destination has been adopted as a strategic tool for destinations around the world, in order to support the provision of tourism experiences to tourists, to efficiently communicate with consumers and to measure and evaluate the competitiveness of the tourism destination. The definition stated by the authors represents a vision that has communication as a central element. The purpose of this communication is to obtain information, process it and then create tourism products and services that would generate the increase of the competitiveness of the tourism destinations.

Vargas-Sánchez (2016) suggests the following definition: the smart tourism destination is based on an extensive use of state-of-the-art technologies in order to create an advanced digital space through an integrated network of management systems, platforms, any kind of data so as to improve the overall management of the destination and to ensure its differentiation and competitiveness.

$\mathrm{Li}$ et al (2016) consider that smart tourism represents the ideal place to meet the tourists' needs and increase their satisfaction, while achieving the distribution and use of resources. Li et al (2016) also appreciate that smart tourism represents an omnipresent tourism information service offered to tourists during the trip and a bilateral flow of information between the tourists and the interested parties (2016). In comparison to the previously formulated approaches, the authors note the role of technology implementation in tourism activities as a means of efficient use of resources (human, financial, material and informational). These resources contribute to the achievement of the objectives of any tourism destination, namely attracting tourists.

Jovicic (2017) formulates an approach according to which the smart tourism destination is a knowledge-based destination, where ICT is used in order to provide 
a platform that allows a quick exchange of information regarding the tourists. According to this point of view, the use of ICT in choosing a tourism destination represents a cognitive process based on tourists' selection of the information obtained from different sources: Internet, specialized tourism sites, travel blogs and tutorials. By using technology, the tourist has very fast access to information sources on tourism products or services $\mathrm{s} / \mathrm{he}$ is interested in.

Vecchio (2017) formulates as the final objective of the smart tourism destination the increase of the tourism experience maximizing the destination competitiveness and consumers' satisfaction paying attention to long-term sustainability. Supplying some tourism products, designed to meet the tourists' needs, leads to a favourable position on the tourism market, in accordance with the principles of a sustainable exploitation and development of natural and anthropogenic tourism resources.

Jasrotia and Gangotia (2018) link smart tourism destinations with smart cities. Starting from this premise, the authors define the smart tourism destination as smart cities that use information technology and innovations to offer pleasures and experiences to tourists. The authors condition the development of smart tourism by the cities where ICT has been successfully implemented. This fact would limit the possibility to develop smart tourism in rural areas, even in case the infrastructure of these places would allow it.

Liberato et al (2018) state that a smart tourism destination should be able to incorporate technological development and develop innovative activities. Moreover, these destinations should also be able to combine these capabilities with digital spaces, information processing and tools, which allow transferring the technology and exchanging knowledge. The authors' approach offer a technical perspective on the concept of smart tourism regarding the implementation of new technologies in the tourism sector.

Serra and Baidal (2018) consider that smart tourism destinations are receiving an increasing attention from government organizations and destination management organizations, by means of policies implemented in many destinations. The same authors (2018) state that the impact of the policies regarding smart tourism destination remains largely unknown. In this context, the destination management organizations (DMO) play a central role in implementing government policies on smart tourism.

Shafiee et al (2019) talk about smart sustainable tourism destination and consider that the major challenge of current tourism destinations is to find solutions, which would allow a smarter use of resources and improve the locals' and residents' quality of life through sustainable means. The authors approach the concept from the point of view of the new directions that should be pursued in the development of tourism activities for tourism destinations.

In Figure 1, a schematic representation of the elements that contribute to the delimitation of the concept of smart tourism destination was created. 


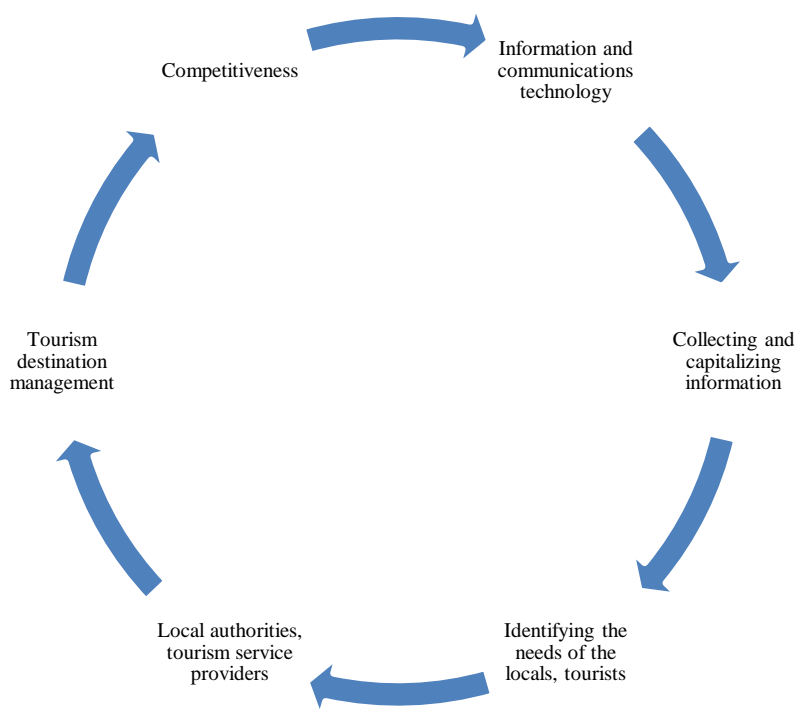

(Source: Made by the author)

Figure 1: Approaching the concept of smart tourism

\section{Limitations and further research}

The smart tourism destination represents a way to correlate the needs of tourists with the interests of the tourism service providers and local authorities by using ICT. This approach of the tourism destination issue represents a common result of all the interested parties so as to ensure the competitiveness of tourism destinations, under the conditions of the ICT implementation in the performance of tourism activities.

This paper represents an attempt to illustrate different points of view regarding the smart tourism destination. The limits of this paper are given by the fact that a selection of specialized papers was made using only the criterion of the number of citations thus, not achieving a global presentation of this issue.

In the future, it would be advisable to study the interdependence between the current approaches of the concept of tourism destination: smart tourism destination, sustainable tourism destination and friendly tourist destination.

\section{References}

1. Buhalis, D. and Amaranggana, A. (2013) 'Smart Tourism Destinations', Information and Communication Technologies in Tourism, pp. 553-564, DOI: 10.1007/978-3-319-03973-2_40.

2. Buhalis, D. and Amaranggana, A. (2014) 'Smart Tourism Destinations Enhancing Tourism Experience Through Personalisation of Services', Information and Communication Technologies in Tourism, pp. 377-389, DOI 10.1007/978-3319-14343-9_28.
3. European
Commission,
Tourism, https://ec.europa.eu/growth/sectors/tourism/offer/sustainable en, [29 Dec 2020]. 
4. Femenia-Serra, F. and Ivars-Baidal, J.A. (2018) 'Do smart tourism destinations really work? The case of Benidorm ', Asia Pacific Journal of Tourism Research, DOI: 10.1080/10941665.2018.1561478, pp. 1-20.

5. Gretzel, U., Kopera, S. and Koo, C. (2015) 'Smart Tourism Challenges', Journal of Tourism, Vol. XVI, No.1, pp. 41-47.

6. Gretzel, U., Sigala, M. and Xiang, Z. (2015) 'Smart tourism: foundations and developments', Electronic market, pp. 314-323.

7. Gretzel, U., Werthner, H., Koo, C. and Lamsfus, C. (2015) 'Conceptual foundations for understanding smart tourism ecosystems', Computers in Human Behavior 50, pp. 558-563.

8. Jasrotia, A. and Gangotia, A. (2018) 'Smart cities to smart destinations: A Review Paper', Journal of Tourism Intelligence and Smartness, Vol. 1, Issue 1, pp. 47-56.

9. Jovicic, D.Z. (2017) 'From the traditional understanding of tourism destination to the smart tourism destination', Current Issues in Tourism, pp. 1-7, DOI: $10.1080 / 13683500.2017 .131320$

10. Lamsfus, C. and Aurkene, Alzua-Sorzabal (2013) 'Theoretical Framework for a Tourism Internet of Things: Smart Destinations', tourGUNE Journal of Tourism and Human Mobility, pp.1-21.

11. Lamsfus, C., Martin, D., Alzua-Sorzabal Aurkene and Torres-Manzanera, E. (2014) 'Smart Tourism Destinations: An Extended Conception of Smart Cities Focusing on Human Mobility', Information and Communication Technologies in Tourism, pp. 363-375, DOI 10.1007/978-3-319-14343-9_27.

12. Li, Y., Hu, C., Huang, C. and Duan L. (2016) 'The concept of smart tourism in the context of tourism information services', Tourism Management, pp. 1-8, http://dx.doi.org/10.1016/j.tourman.2016.03.014.

13. Liberato Costa, P.M., Alén-González, E. and Azevedo Liberato, D.F.V. (2018) 'Digital Technology in a Smart Tourism destination: The Case of Porto', Journal of Urban Techology, DOI: 10.1080/10630732.2017.1413228,pp. 1-47.

14. López-Sánchez, Y. and Pulido-Fernández, J. (2017) 'Factors influencing the willingness to pay for sustainable tourism: a case of mass tourism destinations', International Journal of Sustainable Development \& World Ecology, 24:3, pp. 262-275, DOI: 10.1080/13504509.2016.1203372.

15. Shafiee, S., Ghatari, A.R., Hasanzadeh, A. and Jahanyan, S. (2019) 'Developing a model for sustainable smart tourism destinations: A systematic review', Tourism Management Perspectives, 31, pp. 287-300.

16. Vargas-Sánchez,A. (2016) 'Exploring the concept of smart tourist destination', Enlightening Tourism. A Pathmaking Journal, 6 (2), pp. 178-196.

17. Vecchio, P. (2017) 'Creating value from Social Big Data: Implication for SmartTourism Destinations', Information Processing and Management, pp. 1-13, http://dx.doi.org/10.1016/.ipm.2017.10.006.

18. World Tourism Organisation, Policy and Destination Management, https://www.unwto.org/policy-destination-management, [03 lan 2021].

19. World Tourism Organisation, Tourism Statistics Data, https://www.unwto.org/tourism-statistics-data, [23 lan 2021].

20. Xiang, Z., Tussyadiah, I. and Buhalis, D. (2015) 'Special Issue on Smart Destinations: Foundations, Analytics, and Applications', Journal of Destination Marketing \& Management, 4(3), pp.143-144. 